IZA DP No. 6422

Explaining the Dynamics in Perceptions of Job Insecurity in Russia

Michael Lokshin

Vladimir Gimpelson

Aleksey Oshchepkov

March 2012 


\title{
Explaining the Dynamics in Perceptions of Job Insecurity in Russia
}

\author{
Michael Lokshin \\ World Bank \\ and Higher School of Economics, Moscow \\ Vladimir Gimpelson \\ Higher School of Economics, Moscow \\ and IZA \\ Aleksey Oshchepkov \\ Higher School of Economics, Moscow
}

Discussion Paper No. 6422

March 2012

IZA

P.O. Box 7240

53072 Bonn

Germany

Phone: +49-228-3894-0

Fax: +49-228-3894-180

E-mail: iza@iza.org

\begin{abstract}
Any opinions expressed here are those of the author(s) and not those of IZA. Research published in this series may include views on policy, but the institute itself takes no institutional policy positions.

The Institute for the Study of Labor (IZA) in Bonn is a local and virtual international research center and a place of communication between science, politics and business. IZA is an independent nonprofit organization supported by Deutsche Post Foundation. The center is associated with the University of Bonn and offers a stimulating research environment through its international network, workshops and conferences, data service, project support, research visits and doctoral program. IZA engages in (i) original and internationally competitive research in all fields of labor economics, (ii) development of policy concepts, and (iii) dissemination of research results and concepts to the interested public.
\end{abstract}

IZA Discussion Papers often represent preliminary work and are circulated to encourage discussion. Citation of such a paper should account for its provisional character. A revised version may be available directly from the author. 


\section{ABSTRACT \\ Explaining the Dynamics in Perceptions of Job Insecurity in Russia}

Contrary to the experiences of other countries, perceptions of job insecurity in Russia were not correlated with the rates of unemployment and the business cycle over the last decade. We develop the theoretical framework that predicts that the individual perceptions of job insecurity depend on regional unemployment rates and on the within-group variance of wage distribution faced by workers. We test this hypothesis using data from ten panel rounds of Russia Longitudinal Monitoring Survey. Our results indicate that while higher rates of unemployment make workers feel less job secure, the wage compression during recessions reduces their fears of losing a job. In periods of economic expansion the effect of lower unemployment rates is offset by the higher fears of losing better paying jobs.

JEL Classification: J28, J30, J64

Keywords: $\quad$ unemployment, job security, business cycle, Russia

Corresponding author:

Vladimir Gimpelson

Higher School of Economics

Myasnitskaya Street, 20

Moscow 101987

Russia

E-mail: vladim@hse.ru 


\section{Introduction ${ }^{1}$}

Between the 1998 and 2000, in the wake of fast recovery after the financial crisis of 1998 the unemployment rate in Russia declined from almost 14 percent to less than 9 percent. However, most of the workers who were afraid of losing jobs in 1998 reported similar level of fear in 2000. The strong economic growth of 2000 to 2007 brought unemployment further down to less than 6 percent. Meanwhile, the proportion of respondents who were afraid of losing their jobs decreased just slightly and never was below 50 percent. These high, by international standards, levels of fear manifested itself despite political efforts to "preserve stability" in all dimensions of social life including job protection (Gimpelson and Monusova 2010).

Most of the studies on the fear of unemployment find strong correlation between unemployment rates and levels of the fear of losing a job. Schmidt (1999) for the US and Green, Felstead and Burchell (2000) for the UK show that the fear of unemployment moves in line with the actual unemployment. Even small changes in unemployment translate into significant changes of the level of fear. Clark, Knabe and Ratzel (2009) report similar relationship between the unemployment rates and the levels of perceived job insecurity in Germany. Clark and PostelVinay (2009), using data from 12 OECD countries, find that the regional unemployment rates sharply reduce perceived job security among the temporary workers, but increase that perception among permanent job holders. Though this positive relationship between the unemployment rates and the perceptions of job insecurity seems intuitively obvious and is confirmed by many empirical studies, it does not emerge as universal. In Russia, perceptions of job insecurity were not correlated with movements in the rates of unemployment over the last two decades. In this paper we try to offer an explanation to this phenomenon.

The fear of unemployment among Russian workers was explored in Gimpelson, Kapeliushnikov and Ratnikova (2003), Linz and Semykina (2008, 2010) and Gimpelson and Oshchepkov (2012). These papers report weak or no correlation between the levels of unemployment and the fear of unemployment early in the transition and find small positive correlation in the later years. The authors also note that while in most countries job tenure improves the perception of job security, in Russia, older and more experienced employees report

\footnotetext{
${ }^{1}$ The financial support from the HSE Basic Research Program is acknowledged. We thank Rostilav Kapelushnikov and Ruslan Yemstov for useful and constructive comments.
} 
higher fear of unemployment compared to younger workers. On aggregate, women are more afraid of losing their jobs compared to men, which is not the case in other countries. While presenting a useful descriptive analysis and documenting the effects of individual characteristics on the perception of job insecurity, none of these papers offer a causal explanation for the persistence in fear of unemployment against large fluctuations in unemployment.

In our paper we develop a theoretical framework to analyze the dynamics in the levels of fear of unemployment. This framework predicts that individual perceptions of job insecurity depend on regional unemployment rates and on the within-group variance of wage distribution faced by workers or "residual" wage inequality (e.g., Lemieux 2006). And these two indicators move in the opposite directions over the business cycles resulting in no or low correlation between the fears of losing a job and the rates of unemployment. We test this hypothesis using data from ten panel rounds of the Russian Longitudinal Monitoring Survey. Our results indicate that while higher rates of unemployment make workers feel less job secure, the within-group compression of wage distribution (due to decrease in variable part of wages) during recessions reduces their fears of losing a job. In periods of economic expansion the effect of lower unemployment rates is partially offset by the higher fears of losing better paying jobs.

The countercyclical dynamics of subjective job insecurity may have important policy implications. The persistent fears of joblessness among workers feed public support for populist policies in the labor market. These fears are translated to politicians thus narrowing the political window of opportunities for needed economic reforms and strengthen the sub-optimal equilibrium with negative potential implications for both employment and unemployment.

The next section describes our data and defines main indicators used in the analysis. Section 3 provides information on the Russian labor market over the period of 2000-09. Section 4 describes the theoretical framework and formulates testable hypothesis. Section 5 explains the econometric methodology and Section 6 provides the results of the empirical analysis and simulations. The alternative explanations for our results are tested in Section 7. Section 8 sums up our major findings and suggests some policy implications. 


\section{Data and main definitions}

For this study we use data from ten panel rounds of the Russian Longitudinal Monitoring Survey (RLMS-HSE) covering the 10-year period from Q4 2000 to Q4 2009. Our main sample contains information on 23,378 men and 26,233 women in the working age who were employed and earned wages in any of the ten rounds of the survey ${ }^{2}$.

Our measure of perception of job insecurity is provided by answers to two questions. The fear of losing a job (FLJ) question is formulated as follows: "How concerned you are that you can lose your job? Are you (1) Very concerned; (2) Concerned to some degree; (3) Yes and No; (4) Little concerned; (5) Not at all concerned? To simplify the interpretation of our results, we redefine answers to the FLJ question so that the higher ranks in the answers correspond to higher levels of fear.

The second question inquires about fear of not finding a job (FNFJ): Imagine not a very pleasant situation: the enterprise where you are working now, for some reason will be closed tomorrow and all workers will be fired. How sure you are that you could find a job at least as good as your current one? Are you (1) Absolutely sure (2) Almost sure (3) Yes and No (4) Not very sure (5) No sure at all? All working respondents older than 16 years of age were asked to answer these questions. Table 1 shows the proportion of respondents in each category for both questions by years of the survey.

We use earnings for the last 30 days on the main job as a measure of individual real wages. They were deflated to 2000 prices to insure inter-year comparability. The unemployment rates for our analysis are calculated in three different ways. The first measure of unemployment is an aggregate unemployment rate for each of 27 regions of Russia (RosStat 2011). We also calculate the group-specific unemployment and non-employment rates using data from Russian Labor Force Survey (LFS). The survey collects information on about 265,000 individuals every year and is representative at the regional level (RosStat 2011). We form 496 unique combinations of the region, type of location (urban or rural), gender and education of the respondents in LFS and for each group and for each year, we calculated unemployment rate as a proportion of unemployed in economically active population in the group and non-employment

\footnotetext{
2 The working age for men in Russia is from 16 to 59 years, and for women from 16 to 54 year. See the RLMS-HSE web site for details on data access and sample design: http://www.cpc.unc.edu/projects/rlms-hse.
} 
rate as a proportion of non-employed in the total population in the group. We then impute these values of group-specific unemployment and non-employment rates to every respondent in our RLMS sample.

\section{Labor market dynamics and fear of unemployment in Russia: descriptive analysis}

After peaking at its all-time high of around 14 percent in early 1999 the Russian unemployment rate declined rapidly responding to the economic recovery and dropped below 6 percent by early 2008. The recovery after 1998 crisis had a broad positive impact on the labor market: wage arrears nearly dissipated; underemployment decreased and the number of annual hours worked increased. The problem of excess employment typical for the 90s was replaced by the widelypublicized "threat of labor shortage". Hiring and vacancy rates stayed high. At the same time, the employment in the corporate sector shrank from 52 to 48 million workers (or from 80 to 70 percent of total employment), while the share of temporary or casual jobs and jobs in the informal sector were on the rise (OECD 2011). Between 2000 and 2008, the real wages grew at 12-15 percent per annum (Rosstat 2011). The doubling of minimum wages and increases in the public sector wages in the second half of 2000s accelerated growth in the lower part of the wage distribution. This rapid wage growth was associated with a reduction in unemployment benefits replacement ratio, which declined from 20 percent in 2000 to 7.4 percent in 2008. Consequently, the total costs of unemployment to workers increased ${ }^{3}$.

The effect of economic crisis of 2008-09 on the labor market emerged with a lag. The unemployment rate grew to modest 7 percent by the end of 2008 and reached 8.5 percent in 2009. Positive pre-crisis wage dynamics turned to a slight decline and wage arrears reappeared. Under-employment was also on the rise (RosStat 2011). Expectation of mass lay-offs became a new focus of media attention and a factor of public concern.

Major labor market institutions in Russia were largely shaped in the first half of the 1990s. The Russian Government tried to build market compatible safety nets, on the one hand, but to prevent massive downsizing of the labor force, on the other. High unemployment associated with a large scale displacement that was implicitly considered a significant social and

\footnotetext{
3 Though unemployment benefits were raised notably in the beginning of 2009 as an anti-crisis measure, the replacement ratio remained low at $12.4 \%$.
} 
political threat. As an outcome, the evolved institutional framework allowed for significant wage flexibility (cyclical compression and decompression) but left limited room for rapid employment adjustments.

One of the major job security institutions is employment protection legislation (EPL) which affects firing costs. The Russian EPL inherited multiple rigidities from the old Soviet Labor Code though was weakly enforced in practice. In 2000s, the government labor market policies were focused on providing better job protection to workers by improving enforcement of labor contracts and regulations (Vishnevskaya and Kapelushnikov 2007). At the same time the share of workers in large- and medium-size organizations where the Labor Code was enforceable declined gradually over the whole period from two thirds to half of all employed in the Russian economy (Gimpelson and Kapeliushnikov 2011). That shift of the labor force to the informal sector with a weak enforcement of the Labor Code increased the number of unprotected workers. These developments had ambiguous impacts on actual job security ${ }^{4}$.

On the price side of the labor market, both the minimum wage and unemployment benefits replacement ratios remained low keeping effective wage floor down. Another important wage flexibility instrument on the Russian labor market is the two-tier wage structure. This feature emerged in the early 90s and became soon a systemic characteristic of the wage setting machinery in the private and public sectors. The tariff-based and rigidly contracted basic wage component constitutes, on average, about 60 percent of the wage bill. The other, more flexible wage component includes bonuses and wage premiums that are implicitly linked to financial performance of firms (or revenues of regional/municipal budgets). The fluctuation of the firm's profitability over the business cycle results in corresponding changes in the size of that component. The wage-setting mechanism in the public sector, though heavily regulated, follows similar two-tier approach with the variable part of the public sector wages linked to revenues of local governments that also vary procyclically (Gimpelson and Kapeliushnikov 2011). The variable component in the two-tier wage structure works as a risk-sharing mechanism in the face of high uncertainty in the market environment (Bigsten et al. 2003) assuming an implicit contract between risk-averse workers and risk-averse employers. In a downturn, the variable fraction of wage payment shrinks, containing total labor costs but workers are likely to enjoy an additional

4 Gimpelson and Oshchepkov (2012) demonstrate that employment in informal sector may be negatively correlated with the level of fear of losing a job. 
wage premium in the upturn ${ }^{5}$. For example, in the crisis year of 1998, the variable wage component made up less than 40 percent of the total wage bill. In the prosperous years of 2005 and 2007 it exceeded 45 percent. These trends were observed across all sectors, including the over-regulated education and healthcare. In such setting, a significant portion of labor market related risks is shifted onto workers through the wage channel. In the US, only about 40 percent of workers are on a performance pay, and the median share of performance pay in total earnings is about 4.4 percent (Lemieux, MacLeod and Parent 2007).

We exploit the fact that, in Russia, the variable part of the wage is large, almost universal and linked to firm performance, when we model dynamics of the fear of unemployment. This type of wage flexibility sends mixed signals to workers and may have an ambiguous impact on perceptions of labor market related risks.

\section{Level and Dynamics of Fear of unemployment}

Figure 1 presents the evolution of subjective perceptions of job insecurity in Russia during 20002009. The changes in the levels of FLJ are not correlated with the changes in the aggregate unemployment during the 2000 to 2009 period. In 2000s, the levels of subjective job insecurity were largely stable and high compared to other countries. The proportion of respondents who were concerned or very concerned about losing their jobs was persistently above 50 percent (Table 1) ${ }^{6}$. Russians express fears of losing jobs at levels similar to workers in Latin America where the rigid employment protection legislations cover relatively small formal sector and the modern unemployment protection is almost non-existent (Graham 2003).

The subjective perceptions of Russian workers seem to be very inertial and insensitive to the actual state of the labor market. The thick line on Figure 1 reflects the actual unemployment dynamics. The unemployment rates dropped by almost 50 percent between 2000 and 2007, but the proportion of respondents afraid of losing a job decreased from 69 percent to 53 percent only. The proportion of those who feared of not finding a job in this period declined some more but it

5 Caroli and Garcia-Penalosa (2002) argue that as an economy grows endogenous changes in workers risk aversion induces changes in the wage structure. During the periods of economic growth the individual incomes increase, the degree of risk-aversion of workers falls and they chose contracts with higher proportion of variable wages. In the recessions, more risk-averse workers are more willing to accept fixed-wage contracts as a form of insurance.

6 The proportion of workers who was afraid of losing their jobs in USA and UK in 1990s was less than 10 percent (Aaronson and Sullivan, 1999; Campbell et al. 2007). 
also stayed at the level above 40 percent (except the year 2007). A slight upward turn in the both indicators emerged in late 2008, when the economy started to slide into the new crisis, but then returned to the previous trend in 2009.

Around 70 percent of workers who feared losing job in a given year remained with this fear in the year after that. Those with very strong fears did not change their perceptions even during the period of robust economic growth and of rapid decline in unemployment. Workers perceptions concerning finding a new job if a worker is fired were even more stable over time.

\section{Theoretical framework}

Suppose that the individual $i$ 's utility $U_{i}$ depends positively on her current wages $\left(w_{i}\right)$ and other factors $X_{i}$ that might include individual and household characteristics. On the job market, an individual faces a stream of job offers that are independent random draws from the distribution of wages. The mean of that distribution is determined by the returns on individual's characteristics (both observed and unobserved). The offers occur periodically and either accepted or rejected. Under these conditions of the standard job search theory (e.g., McCall 1970, Mortensen 1986) the individual will reject all offers below (and stays unemployed) and accept the offers above a certain threshold, which is an individual reservation wage. We can think of current wage $w_{i}$ as a sum of the individual's expected wage $w_{i}^{*}$ and a positive wage shock $\mu_{i}$. For example, wages might consist of defined fixed component and bonuses and premiums. Once a job offer is accepted it is costly for the employee and for the employer to renegotiate the conditions of the work contract.

When employed, the individual obtains utility:

$$
U_{i}^{\text {Employed }}=U\left(w_{i}, X\right)
$$

The expected utility of an individual if fired consists of two parts:

$$
E\left[U_{i}^{\text {Fired }}\right]=P\left(Z_{i}, w_{i}^{*}\right) U\left(w_{i}^{*}, X_{i}\right)+\left(1-P\left(Z_{i}, w_{i}^{*}\right)\right) U\left(b, X_{i}\right)
$$

where $P\left(w_{i}^{*}, Z_{i}\right)$ is the probability of finding an employment with a wage $w_{i}^{*}$, that is also a function of a vector of characteristics $Z_{i}$, and $b$ is an amount of unemployment benefits. The first part in (2) is the product of the probability of finding a new employment and utility derived from expected earnings at the new job. The second part is the utility derived from unemployment 
benefits if the person fails to find gainful employment. The higher is the expected wage the less likely the individual finds a job with such a wage, i.e., $\partial P\left(w_{i}^{*}, Z_{i}\right) / \partial w_{i}^{*}<0$.

We can think of the fear of losing a job $F_{i}$ as a difference between utilities of being employed and the expected utility if unemployed ${ }^{7}$ :

$$
\begin{aligned}
F_{i}=U_{i}^{\text {Employed }}-E\left[U_{i}^{\text {Fired }}\right] & \\
& =U\left(\left(w_{i}^{*}+\mu_{i}\right), X_{i}\right)-\left\{P\left(Z_{i}, w_{i}^{*}\right) U\left(w_{i}^{*}, X_{i}\right)+\left(1-P\left(Z_{i}, w_{i}^{*}\right)\right) U\left(b, X_{i}\right)\right\}
\end{aligned}
$$

Differentiating (3) with respect to $w_{i}^{*}, P\left(Z_{i}, w_{i}^{*}\right)$ and $\mu_{i}$ results in:

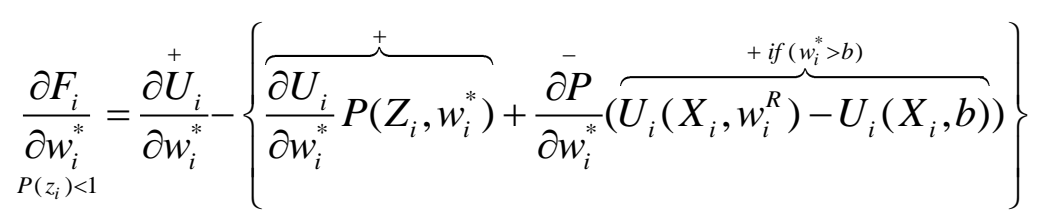

$$
\begin{aligned}
& \frac{\partial F_{i}}{\partial \mu_{i}}=\frac{\partial \stackrel{+}{U}_{i}}{\partial \mu_{i}}>0 \\
& \frac{\partial F_{i}}{\partial P}=-U\left(w_{i}^{*}, X_{i}\right)+U\left(b_{i}^{+}, X_{i}\right)<0
\end{aligned}
$$

This simple framework provides us with testable hypotheses about the effect of wages and the probability of finding a job on the fear of being unemployed. Under the standard assumptions about the form of the utility function $U_{i}$, the fear of losing a job is higher the higher is the wage shock component $\mu_{i},\left(\frac{\partial F_{i}}{\partial \mu_{i}}>0\right)$ in (5). The fear is decreasing when the probability of finding a job goes up $\left(\frac{\partial F_{i}}{\partial P}<0\right)$ as in (6). An individual is less afraid of being unemployed the smaller is the difference between his market wages and the benefits he might receive if unemployed ${ }^{8}$ The effect of expected wages on the fear of losing a job is ambiguous. The difference between the current and expected wages is lower for individuals with higher expected wage thus lowering the

\footnotetext{
7 Nickell, Jones, and Quintini (2002) define the job insecurity as an expected loss in income if unemployed compared to the current state. Green, Felstead and Burchell (2000) relate job insecurity with the costs of job loss. Similarly to our model, these costs depend on wages on the current job, benefits while unemployed, duration of unemployment and expected wages on the next job. Luechinger, Meier and Stutzer (2009) point that the negative effect of unemployment on people's well-being is driven mostly by worries about economic distress as a result of losing their job.

${ }^{8}$ This result finds empirical confirmation in Clark and Postel-Vital (2009) who report that feelings of job security are positively related with the size of unemployment benefits in OECD countries.
} 
fear of losing a job. At the same time, the probability of finding a job is inversely related to wages an individual pretends to get.

This theoretical framework describes the dynamics of changes in the attitudes towards the event of losing a job over the business cycle. When the economy is expanding, the unemployment is low and the variable components of wages (for example, bonuses or premiums) $\operatorname{are~high~}^{9}$. On one hand, the individual is afraid of losing her high-paying job; on the other hand, her fear of being fired is low as she can easily find a new employment. In the recessions, the unemployment is higher and the probability of finding a new job if laid off is lower. At the same time, the wages the individual can earn on the market are also low because the bonuses and premiums are reduced. It is harder to find a new job, but the current and the new jobs are less rewarding compared to the periods of economic growth.

\section{Econometric methodology}

The hypothesis outlined in the previous section can be tested empirically. Assume that the latent fear of losing a job for an individual $i$ is a function of the set of characteristics:

$$
F_{i}^{*}=F_{i}\left(\mu_{i}, P\left(Z_{i}, w_{i}^{*}\left(X_{i}\right)\right), X_{i}, \varepsilon_{i}\right)
$$

where $\varepsilon_{i}$ is a vector of unobserved factors that affect the fear of losing a job. The random component of wages $\mu_{i}$ can be estimated as a residual of the standard Mincer's wage equation (Mincer 1974).

$$
w_{i}=\vartheta X_{i}+\mu_{i} ; \hat{\mu}_{i}=w_{i}-\hat{\vartheta} X_{i}
$$

In the linearized form (7) can be rewritten as:

$$
F_{i}^{*}=\pi \hat{\mu}_{i}+\gamma P_{i}+\beta X_{i}+\varepsilon_{i}
$$

where $\pi, \gamma$, and $\beta$ are unknown parameters. The observed answers to FLJQ are:

$$
\begin{array}{lll}
F_{i}=1 \text { if } & F_{i}^{*} \leq 0 \\
F_{i}=2 \text { if } & 0 \leq F_{i}^{*} \leq \theta_{1}, \\
\cdots & & \\
F_{i}=5 \text { if } & \theta_{4} \leq F_{i}^{*}
\end{array}
$$

\footnotetext{
${ }^{9}$ The theoretical model and empirical analysis in Robin (2011) demonstrate the pro-cyclical dynamics of the wage inequality in upper part of wage distribution.
} 
$\theta$ 's are unknown parameters to be estimated. The probability of observed answers to FLJQ is:

$$
\begin{gathered}
\operatorname{Pr}\left[F_{i}=j\right]=\Phi\left(\theta_{j}-\pi \hat{\mu}_{i}-\gamma P_{i}-\beta X_{i}\right)-\Phi\left(\theta_{j-1}-\pi \hat{\mu}_{i}-\gamma P_{i}-\beta X_{i}\right) \\
j=1, \ldots, 5 ; \theta_{0}=-\infty ; \theta_{5}=+\infty
\end{gathered}
$$

where $\Phi(\cdot)$ is a probability distribution function. Assuming that $\varepsilon_{i}$ is i.i.d and distributed normally across the observations, the conditional probabilities for the answers to FLJQ can be estimated by the standard maximum likelihood ordered probit (OP) estimator. Relaxing the distributional assumptions, parameters of (11) can be estimated by semi-nonparametric maximum likelihood (SNPML) estimator proposed by Gallant and Nuchka $(1987)^{10}$.

The estimation of the parameters in equations (9-10) could be complicated by the potential endogeneity of $\mu_{i}$ that arises both from the reverse causality and omitted variable argument, i.e., $\mu_{i}$ could be correlated with $\varepsilon_{i}$ in (9). For example, risk-averse individuals might accept stable jobs with lower compensation (Blanchflower 1991; Aaronson and Sullivan 1999; Clark and Postel-Vinay 2009). Or, somebody with connections to the enterprise management can land the high paying and secure position.

We address this endogeneity by assuming that $\mu_{i}$ consists of time-invariant component $v_{i}$ and time-variant component $\rho_{i t}$. A degree of risk aversion or personal networks are unobserved by the researcher, time-invariant factors that might affect both the individual's fear of losing a job, his wages as well as his probability of finding a new job. We assume that the wage negotiations between the employee and the employer happened before the moment when the fear of losing a job is assessed through the survey interview. $\rho_{i t}$ is unknown to the individual at time of signing a job contract and thus is correlated neither with the agreed compensation nor with the fear of losing a job. We also assume that, conditional on time-invariant component $v_{i}$, perceptions of job security are not correlated over time, i.e.:

$$
\operatorname{Corr}\left(F_{i, t-1}, F_{i, t} \mid v_{i}\right)=0
$$

Under these assumptions we can remove the source of endogeneity by utilizing the panel structure of our data and estimating the fixed effect $(\mathrm{FE})$ wage regression:

$$
w_{i t}=\vartheta X_{i t}+\mu_{i t}=\vartheta X_{i t}+\left(v_{i}+\rho_{i t}\right)
$$

where subscript it indicates an observation for individual $i$ at time period $t$. We use the estimate of $\hat{\rho}_{i t}$ from the FE regression to obtain the unbiased estimates of the parameters in equation (11).

\footnotetext{
10 This estimator is implemented as STATA command sneop (Stewart, 2004).
} 
The dependent variable in wage equations (8) and (13) is the logarithm of monthly earnings expressed in 2000 prices. We use three different concepts of regional levels of unemployment as variables that affect workers perception about the probability of finding a job if fired. The set of explanatory variables includes the individual's age and age squared, marital status, level of education, work tenure in years and tenure squared, the size and composition of the household the respondent resides in, type of the locality, and year and regional dummies. The descriptive statistics for the explanatory variables used in our model are shown in Table 2.

\section{Results}

The results of estimations of (11) for different econometric specifications are presented in tables 3-5. Table 3 shows the estimations of the ordered probit with the wage residual imputed from OLS regression as in (8). The coefficients on the wage residual are positive and significant for both male and female workers. The coefficients on regional unemployment rate are positive for both genders but are significant only for female workers. Table 4 demonstrates the estimations of the ordered probit with wage residuals imputed from the FE regression as in (13). The sample size for these estimations is smaller as it includes individuals observed at least in two rounds of our survey. The coefficients on the wage residuals and on the regional unemployment have similar signs and magnitudes as in Table 3. Finally, Table 5 presents estimations of SNPML model with wage residuals imputed from the FE regression. This least restrictive model is our preferred specification that produces the coefficients consistent with the coefficients of the previous two estimations. The results of these three estimations confirm the predictions of our theoretical model. Respondents with higher wage residuals have higher levels of job insecurity. Individuals residing in the regions with higher unemployment are more afraid of losing their jobs, compared to individuals from the regions with less unemployment. Interestingly, Keane, Moffitt and Runkle (1988) report very similar results for US where they found that "...those having a particularity good temporary wage draw appear to be more vulnerable to transitory negative employment shocks than those with a temporarily bad wage draw."

Figure 2 shows the non-parametric estimations of the relationship between the wages and wage residuals and the fear of losing a job. The top two panels indicate that both for male and female workers the levels of fear are higher the larger are the OLS and FE wage residuals. At the 
same time, fear of losing a job is declining for individuals with higher wages. These relationships are consistent with the predictions of our economic model. Because wages consist of expected wage part and the residual (variable) part, the negative effect of higher expected wages on fear of unemployment (higher expected wages result in lower fears) dominates the positive effect of potentially higher variable wage component.

The coefficients on other variables demonstrate the expected regularities. The fears of unemployment are increasing with age reaching maximum for 50 years old men and 45 years old women - results similar to findings by Gimpelson, Kapeliushnikov and Ratnikova (2003) and Linz and Semykina (2008), but opposite to those found in most of the literature on subjective measures of well-being (e.g., Clark, Oswald and Warr 1996). Better-educated workers are less afraid of losing their jobs compared with workers with lower education. Married men feel less security on the job than single men, but married women are less afraid of losing their jobs compare to single women. This might be explained by the different social norms of males and females in Russian society. Men are considered to be main breadwinners responsible for the wellbeing of the whole family. A loss of a job for a married man not only results in a largest shock to the family budget ${ }^{11}$, but also has serious psychological impact (Ashwin and Lytkina 2004). The fears of unemployment are the lowest in Moscow and Saint Petersburg and are higher the smaller is the size of locality the respondents reside in. Large urban areas typically have more jobs to offer, and in case of displacement, re-employment takes less time and associated with smaller losses in earnings. The larger share of pensioners and consequently the higher proportion of non-wage income in the household budget positively affect the perception of job security of men but have no effect on that perception among women.

The coefficients in the wage regressions are consistent with the results of previous studies. Wages are lower in the regions with higher unemployment; are increasing with age and educational level; married men earn more than single men; work tenure is positively correlated with monthly earnings; women living in Moscow and St. Petersburg earn more relative to women residing in smaller cities and towns.

We can use the Fear of Not Finding a Job (FNFJ) question to verify the results of FLJ estimation. We expect that respondents with higher wage residuals and those living in high-

\footnotetext{
${ }^{11}$ Wages of male workers were, on average, 20 percent higher than the wages of female workers in Russia in $2000 \mathrm{~s}$ (Dohmen, Lehmann and Zaiceva 2008).
} 
unemployment areas would be more concern with finding a job at least as good as the current one in case they are laid off. Table 6 shows the coefficients on wage residuals and regional levels of unemployment for three econometric specifications corresponding to those shown in Table 35 for FLJ question. The coefficients on wage residuals and regional unemployment rates are positive and significant in all three specifications confirming the results of FLJ estimations.

\section{Robustness tests}

To test the robustness of our results we re-estimate equations (10-13) with group-specific regional unemployment rates and non-employment rates derived from Russian LFS as described in Section 2. We show the results of these estimations in Table 7. The signs and magnitudes of the coefficients on the main variables of interest, the imputed wage residuals and unemployment/non-employment rates, are consistent with those of the coefficients in the main specification. Individuals with larger wage residuals and those residing in the areas of more unemployment report higher levels of job loss fears.

We estimated our econometric models on the pooled samples with a different number of rounds. These estimations are available from the authors on request. The results of these estimations are also consistent with our main findings.

\section{Simulations}

We illustrate the magnitudes of the effect of wage residuals by simulating the changes in the perceptions of job insecurity under the counterfactual scenario where the individual wage residuals are constant over the years of the survey and equal to the wage residuals in 2000. Figure 3 shows the observed and simulated trends in the proportion of male and female respondents who are concerned and very concerned about the prospects of losing their jobs and the unemployment rates. If our hypotheses are correct, we expect that after controlling for the changes in the wage residuals the simulated changes in the proportions of fearful individuals would follow changes in the unemployment rates more closely. Indeed, compared to the observed levels, the simulated levels of fear are lower for all years after the base year and are stronger correlated with the levels of unemployment. On the aggregate level, the correlation with the unemployment rate jumps from 0.012 for the observed levels of fears to 0.310 for the 
simulated level for male workers and that correlation increases from 0.262 to 0.767 for females. The intra-regional correlations, or the correlations between the regional levels of fear with the regional levels of unemployment, exhibit similar patters increasing from 0.371 to 0.560 for males and from 0.439 to 0.638 for females.

\section{Alternative explanations}

We can propose alternative explanations of the changes in the fear of losing a job. The first theory assumes that answering this question a respondent implicitly evaluates probability of losing (being fired) his/her job but no utility comparisons are involved in this reasoning. In this framework, the changes in the answers to FLJ question over time should be correlated with the changes in the levels of unemployment in the individual's reference group. During recessions, when unemployment is high the respondents would perceive higher probability of losing their jobs and select higher values in FLJ question, thus indicating greater concerns. In the periods of economic growth, on the contrary, lower perceived probabilities of losing a job should be translated into lower values of the FLJ question. We find no empirical evidence supporting this hypothesis. Levels of job insecurity are only weakly, if at all, correlated with the aggregate levels of unemployment (Figure 1) and there are other factors, such as within-group wage inequality that are important in determining the dynamics of the fears of losing a job.

The second approach explains the changes in fear of losing a job by the personal trait (or disposition) theory. Traits are habitual patterns of thoughts and emotions that are stable over time but differ across individuals and influence individual behavior. In this approach, the answers to FLJ question reflect the common psychological background prevalent in the current population. Such background is formed over the long period of time by history, religion and culture and is not responsive to the short-run fluctuations in the economic conditions. This explanation for the trends and distribution of fear across countries was suggested by Treisman (2011) ${ }^{12}$ and can be used for explaining the persistently high levels of job insecurity in Russia. The personal trait theory implies that changes in the unemployment rates and in variances of wages have no effect on the changes in the fear of losing a job. Our estimations indicate that both regional

\footnotetext{
12 Treisman (2011) does not explicitly discuss fears of unemployment and his work focuses on the levels of fear rather than on the changes.
} 
unemployment rates and the variance in wages are important determinants of the individual perceptions of job insecurity.

Another explanation for the observed dynamics in fears of losing a job in Russia could be related to a possible non-random selection to unemployment of individuals with the highest perception of job insecurity (Stephens 2004; Luechinger, Meier and Stutzer 2009; Clark and Postel-Vinay 2009; Dickerson and Green 2012). Then, during the recessions, the individuals who are the most concerned about losing their jobs are more likely to become unemployed, thus reducing the aggregate levels of fear. In the periods of economic growth, these people are hired back bringing in the pool of employed their heightened feelings of job insecurity. To test this hypothesis we estimate the probability of becoming unemployed in the current year as a function of the fears of losing a job in a previous year and the set of individual characteristics. The results of these estimations are shown in Table A1 in Appendix. For both males and females the coefficients on the dummy variable indicating that the respondents were concerned and very concerned about losing their job during the last year are as likely to become unemployed in the current year as the respondents with better perception of job security.

\section{Conclusion}

In this paper we explore factors affecting perceptions of job (in)security. In most countries for which empirical evidence is available such perceptions change cyclically: fear of unemployment tends to increase along with rise in unemployment and then declines when unemployment goes down. We document a counter-intuitive case observed in Russia over last two decades when the perceptions remain stable regardless of what actually happens on the labor market, and then offer an explanation.

Our theoretical framework is based on the assumption that for a worker the fear of losing a current job can be expressed as a difference between utility of being employed and the expected utility if she is unemployed. Modeling the utility of being employed we exploit the fact that wages in Russia typically have two-tier structure with a large and time-varying variable fraction. Wage rise if achieved through inflation of this variable part increases utility of the current job but also increases fear of losing this job. During economic crises, wages decline mostly due to the reduction in the variable part, what, in turn, may decrease utility of the job. 
Counter-cyclical movements of wages and unemployment rates are likely to offset each other in terms of their causal impact on subjective job insecurity.

Our empirical analysis is based on data from ten rounds of the Russian Longitudinal Monitoring Survey spanning from 2000 to 2009. The estimations support our theoretical expectation that respondents with higher wage premium (over the basic expected wage) have higher levels of subjective job insecurity while higher unemployment makes individuals more afraid of losing their job. These results are robust to a wide range of model specifications and estimation technique. Basing on these econometric findings, we also examine the counterfactual scenario for dynamics of fear under the assumption that the variable part of earnings (modeled as individual wage residuals) over time remains constant. The simulated levels of fear appear to be lower for all years after the base year and are better correlated with the levels of unemployment.

Persistent level of fear may have important politico-economic implications. Reforming labor market institutions in Russia should lead to more efficient allocation and utilization of labor but involves further deregulation and potential displacement. Because of the strong fears of unemployment in Russian population, these reforms may face additional resistance. Moreover, there is, and probably, will be social and political pressure for stricter job protection, making employers reluctant to hire new workers, leading to longer unemployment spells and higher unemployment (Luechinger, Meier and Stutzer 2009). Politicians reacting to subjective perceptions of voters are likely to freeze or postpone economic reforms if these reforms bring more labor market volatility. Therefore, workers' fear of unemployment becomes politicians' fear and may stimulate the government to pursue populist political actions. This, in its turn, threatens to reduce the number of protected jobs further, causing thus even stronger fears.

For disentangling this vicious circle, systemic measures targeted at improving business climate in order to boost job creation should be a key priority. Strong inflow of jobs is the best social protection and can convince people that job loss is not a doomsday but just an episode which can open new opportunities. 


\section{References}

Aaronson, D. and D. Sullivan. (1999). “Worker insecurity and aggregate wage growth,” Working Paper Series WP-99-30, Federal Reserve Bank of Chicago.

Ashwin, S. and T. Lytkina. (2004). "Men in Crisis in Russia: The Role of Domestic Marginalization," Gender and Society, Vol. 18(2): 189-206.

Bigsten, A. P.Collier, S.Dercon, M.Fafchamps, B.Gauthier, J.Gunning, A.Oduro, R. Oostendorp, C.Pattillo, M.Soderbom, F.Teal, A.Zeuback. (2003). "Risk Sharing in Labor Markets". The World Bank Economic Review. 17 (3): 349-366.

Blanchflower, D. (1991). "Fear, Unemployment and Pay Flexibility," Economic Journal, Vol. 101(406): 483-496.

Campbell, D., Carruth, A., Dickerson, A. and F. Green (2007) "Job Insecurity and Wages," Working paper series \#0813, University of Kent.

Caroli, E. and C. Garcia-Penalosa. (2002). "Risk aversion and rising wage inequality." Economic Letters, Vol. 77(1): 21-26.

Clark, A., Oswald, A. and P. Warr. (1996). “Is Job Satisfaction U-shaped in Age?" Journal of Occupational and Organizational Psychology, Vol. 69: 57-81.

Clark, A., Knabe, A., and S. Ratzel. (2008). "Boon or Bane? Unemployment, Well-being and Job Insecurity," Working Paper 2501, CESIFO.

Clark, A. and F. Postel-Vinay. (2008). "Job Security and Job Protection," Oxford Economic Papers, Vol. 61: 207-239.

Dickerson, A. and F. Green. (2012) "Fears and realisations of employment insecurity." Labour Economics, Vol. 19(2): 198-210.

Dohmen, T., Lehmann, H. and A. Zaiceva. (2008). “The Gender Earnings Gap inside a Russian Firm: First Evidence from Personnel Data - 1997 to 2002," ESCIRRU Working Paper No. 06.

Gallant, R. and D. Nychka. (1987). "Semi-Nonparametric Maximum Likelihood Estimation”, Econometrica, Vol. 55: 363-390.

Gimpelson, V., R. Kapeliushnikov and T. Ratnikova. (2003). Does Fear Have Big Eyes? Fear of Unemployment and Wage Flexibility in Russia. HSE Working Paper WP3/2003/04

Gimpelson, V. and R. Kapeliushnikov. (2011). Labor Market Adjustment: Is Russia Different? IZA Discussion Paper No.5588.

Gimpelson, V. and G. Monusova. (2010). "Fear of Unemployment: Cross-Country Comparisons," Voprosu Economiki, Vol. 2: 42-67.

Gimpelson, V. and A. Oschchepkov. (2012). "Does More Unemployment Cause More Fear of Unemployment?” Working paper BRP 13/EC/2012, Higher School of Economics, Moscow, Russia

Graham, C. (2002). "Public Attitudes Matter: A Conceptual Frame for Accounting for Political Economy in Safety Nets and Social Assistance Policies", The World Bank, SPDP Series No.0233. 
Green, F., Felstead, A., and B. Burchell. (2000) "Job Insecurity and the Difficulty of Regaining Employment: an Empirical Study of Unemployment Expectations," Oxford Bulletin of Economics and Statistics, Vol. 62: 855-883.

Keane, M., Moffitt, R., and D. Runkle. (1988) "Real Wages over the Business Cycle: Estimating the Impact of Heterogeneity with Micro Data," Journal of Political Economy, Vol. 96(6) 1232-1266.

Lemieux, T., MacLeod, W. and D. Parent. (2009). "Performance Pay and Wage Inequality." Quarterly Journal of Economics, Vol. 124(1): 1-49

Lemieux, T. (2006). "Increasing Residual Wage Inequality: Composition Effects, Noisy Data, or Rising Demand for Skill?" American Economic Review, Vol. 1(3): 461-498.

Linz, S., and A. Semykina. (2010) "Perceptions of economic insecurity: Evidence from Russia," Economic Systems, Vol. 34(4): 357-385.

Luechinger, S., Meier, S. and A. Stutzer. (2009) "Why Does Unemployment Hurt the Employed? Evidence from the Life Satisfaction Gap between the Public and the Private Sector." Journal of Human Resources, Vol. 45(4): 998-1045.

Nickell, S., Jones, P., and G. Quintini. (2002). "A Picture of Job Insecurity Facing British Men,” Economic Journal, Vol. 112(1): 1-27.

McCall, J. (1970). "Economics of Information and Job Search", Quarterly Journal of Economics, Vol. 84(1): 113-126.

Mortensen, D. (1986) “Job Search and Labor Market Analysis." In Ashenfelter, O., and R. Layard ed. Handbook of Labor Economics, Vol. II, Elsevier Science Publishers

Mincer, J. (1974). Schooling, Experience and Earnings. Ashgate Publishing Company: Brookfield, VT.

OECD (2011). The Labour Market and Social Policy Review. The Russian Federation. Paris: OECD.

Robin, J. (2011). "On the Dynamics of Unemployment and Wage Distribution," Econometrica, Vol. 79(5): 1327-1355.

ROSSTAT (2011). Trud I zanyatost v Rossii, (Labor and Employment in Russia, 2011. Statistical yearbook).

(2010). "Methodological practices," http://www.gks.ru/bgd/free/meta_2010/Main.htm

Schmidt, S., (1999) "Long-term Trends in Workers' Beliefs about their own job security: Evidence from the General Social Survey," Journal of Labor Economics, Vol. 17: 127141.

Stephens, M. (2004). “Job Loss Expectations, Realizations, and Household Consumption Behavior," Review of Economics and Statistics, Vol. 86(1): 253-269.

Stewart, M. (2004). "Semi-nonparametric estimation of extended ordered probit models." Stata Journal, Vol. 4(1): 27-39.

Treisman, D. (2011). The Georgraphy of Fear. NBER Working Paper No.16838. 
Table 1: Distribution of the answers to Fear of Losing Job question. The percent of responses by category in each year*. RLMS 2000-2009.

\begin{tabular}{|c|c|c|c|c|c|}
\hline & \multicolumn{5}{|c|}{ How concerned you are that you can lose your job? } \\
\hline $\begin{array}{l}\text { Rounds of } \\
\text { RLMS }\end{array}$ & $\begin{array}{c}\text { Not concerned } \\
\text { at all }\end{array}$ & $\begin{array}{l}\text { Not very } \\
\text { concerned }\end{array}$ & Yes and No & $\begin{array}{l}\text { Somewhat } \\
\text { Concerned }\end{array}$ & $\begin{array}{c}\text { Very } \\
\text { concerned }\end{array}$ \\
\hline 2000 & 14.10 & 16.61 & 10.73 & 24.40 & 34.15 \\
\hline 2001 & 18.69 & 18.16 & 10.78 & 23.43 & 28.94 \\
\hline 2002 & 17.80 & 18.23 & 10.81 & 26.27 & 26.90 \\
\hline 2003 & 16.90 & 19.29 & 12.37 & 25.56 & 25.87 \\
\hline 2004 & 16.28 & 18.99 & 11.85 & 27.27 & 25.61 \\
\hline 2005 & 12.66 & 18.91 & 12.86 & 29.48 & 26.09 \\
\hline 2006 & 14.12 & 19.35 & 14.16 & 29.24 & 23.12 \\
\hline 2007 & 14.83 & 19.35 & 12.14 & 30.92 & 22.75 \\
\hline 2008 & 12.66 & 17.71 & 11.49 & 31.52 & 26.63 \\
\hline 2009 & 12.02 & 17.44 & 13.27 & 29.84 & 27.44 \\
\hline \multirow[t]{3}{*}{ Total } & 14.79 & 18.45 & 12.17 & 28.21 & 26.39 \\
\hline & \multicolumn{5}{|c|}{ How sure you are that you could find a job at least as good as your current one } \\
\hline & $\begin{array}{c}\text { Absolutely } \\
\text { sure }\end{array}$ & $\begin{array}{c}\text { Almost } \\
\text { sure }\end{array}$ & Yes and No & $\begin{array}{c}\text { Not very } \\
\text { sure }\end{array}$ & $\begin{array}{c}\text { Not sure } \\
\text { at all }\end{array}$ \\
\hline 2000 & 13.83 & 18.50 & 15.89 & 26.23 & 25.55 \\
\hline 2001 & 19.71 & 20.52 & 14.48 & 23.95 & 21.34 \\
\hline 2002 & 18.00 & 21.63 & 15.14 & 24.02 & 21.21 \\
\hline 2003 & 16.03 & 23.91 & 15.55 & 25.26 & 19.26 \\
\hline 2004 & 14.21 & 23.60 & 17.86 & 25.21 & 19.12 \\
\hline 2005 & 12.75 & 26.07 & 17.52 & 25.32 & 18.35 \\
\hline 2006 & 16.77 & 26.82 & 17.04 & 23.80 & 15.58 \\
\hline 2007 & 16.81 & 30.34 & 16.75 & 22.48 & 13.61 \\
\hline 2008 & 13.88 & 28.68 & 17.28 & 24.73 & 15.42 \\
\hline 2009 & 14.25 & 25.12 & 17.78 & 22.80 & 20.05 \\
\hline Total & 15.57 & 25.04 & 16.65 & 24.26 & 18.48 \\
\hline
\end{tabular}

${ }^{*}$ The answers to Fear of Losing Job, (but not Fear of not Finding a Job) question are redefined relative to the answers in the questionnaire so that the higher categories correspond to higher levels of fear. 
Table 2: Descriptive statistics for the main variables used in the analysis. Pooled sample of working age adults, 2000-2009 RLMS.

\begin{tabular}{|c|c|c|c|c|}
\hline & \multicolumn{2}{|c|}{ Men } & \multicolumn{2}{|c|}{ Women } \\
\hline & Coefficient & Standard Error & Coefficient & Standard Error \\
\hline Log Real wage & 8.718 & 0.693 & 8.723 & 0.694 \\
\hline Regional unemployment & 7.309 & 3.350 & 7.308 & 3.367 \\
\hline \multicolumn{5}{|l|}{ Individual Characteristics } \\
\hline Age in year & 39.174 & 12.063 & 39.852 & 11.953 \\
\hline Receives pension & 0.134 & 0.341 & 0.162 & 0.368 \\
\hline \multicolumn{5}{|l|}{ Education } \\
\hline Incom. Secondary & 0.071 & 0.257 & 0.054 & 0.225 \\
\hline Incom. secondary/vocational & 0.038 & 0.192 & 0.022 & 0.148 \\
\hline Secondary School & 0.207 & 0.405 & 0.183 & 0.386 \\
\hline Secondary + vocational & 0.177 & 0.382 & 0.139 & 0.346 \\
\hline College degree & 0.250 & 0.433 & 0.313 & 0.464 \\
\hline University and higher & 0.254 & 0.435 & 0.287 & 0.453 \\
\hline Work tenure & 7.176 & 8.948 & 8.020 & 9.399 \\
\hline Married & 0.721 & 0.448 & 0.645 & 0.478 \\
\hline \multicolumn{5}{|l|}{ Household Characteristics } \\
\hline Log of household size & 1.130 & 0.428 & 1.087 & 0.445 \\
\hline Share of children & 0.148 & 0.179 & 0.145 & 0.181 \\
\hline Share of pensioners & 0.078 & 0.189 & 0.081 & 0.194 \\
\hline \multicolumn{5}{|l|}{ Type of locality } \\
\hline Moscow/St. Petersburg & 0.132 & 0.339 & 0.135 & 0.342 \\
\hline City & 0.330 & 0.470 & 0.331 & 0.471 \\
\hline Town & 0.285 & 0.452 & 0.285 & 0.451 \\
\hline Small Town & 0.054 & 0.226 & 0.057 & 0.232 \\
\hline Village & 0.199 & 0.399 & 0.192 & 0.394 \\
\hline \multicolumn{5}{|l|}{ Federal Regions } \\
\hline North-Western & 0.283 & 0.450 & 0.283 & 0.450 \\
\hline Central & 0.114 & 0.318 & 0.122 & 0.328 \\
\hline South & 0.133 & 0.339 & 0.129 & 0.335 \\
\hline Volga river Region & 0.233 & 0.422 & 0.231 & 0.422 \\
\hline Ural Region & 0.078 & 0.267 & 0.077 & 0.266 \\
\hline Siberia & 0.117 & 0.322 & 0.120 & 0.325 \\
\hline Far Eastern & 0.043 & 0.203 & 0.038 & 0.191 \\
\hline \multicolumn{5}{|l|}{ Yeas of RLMS } \\
\hline 2000 & 0.070 & 0.256 & 0.070 & 0.255 \\
\hline 2001 & 0.081 & 0.273 & 0.081 & 0.273 \\
\hline 2002 & 0.086 & 0.280 & 0.086 & 0.280 \\
\hline 2003 & 0.091 & 0.287 & 0.092 & 0.289 \\
\hline 2004 & 0.095 & 0.294 & 0.095 & 0.294 \\
\hline 2005 & 0.096 & 0.295 & 0.094 & 0.292 \\
\hline 2006 & 0.117 & 0.321 & 0.117 & 0.322 \\
\hline 2007 & 0.119 & 0.324 & 0.119 & 0.323 \\
\hline 2008 & 0.123 & 0.329 & 0.123 & 0.329 \\
\hline 2009 & 0.121 & 0.326 & 0.122 & 0.328 \\
\hline Number of observations & \multicolumn{2}{|c|}{23,248} & \multicolumn{2}{|c|}{23.378} \\
\hline
\end{tabular}


Table 3: Fear of Losing a Job. Ordered probit estimation and OLS estimation for wage equations for men and women. Pooled sample of working age adults, 2000-2009 RLMS.

\begin{tabular}{|c|c|c|c|c|c|c|c|c|}
\hline & \multicolumn{4}{|c|}{ Men } & \multicolumn{4}{|c|}{ Women } \\
\hline & \multicolumn{2}{|c|}{ Ordered probit } & \multicolumn{2}{|c|}{$\begin{array}{c}\text { OLS } \\
\text { Wage regression }\end{array}$} & \multicolumn{2}{|c|}{ Ordered probit } & \multicolumn{2}{|c|}{$\begin{array}{c}\text { OLS } \\
\text { Wage regression }\end{array}$} \\
\hline & Coeff. & Std.Err & Coeff. & Std.Err & Coeff. & Std.Err & Coeff. & Std.Err \\
\hline Log Wage Residuals & $0.042^{* * *}$ & 0.010 & & & $0.072^{* * *}$ & 0.010 & & \\
\hline $\begin{array}{l}\text { Regional unemployment } \\
\text { Individual Characteristics }\end{array}$ & 0.004 & 0.004 & $-0.010^{* * * *}$ & 0.002 & $0.015^{* * *}$ & 0.003 & $-0.011^{* * *}$ & 0.002 \\
\hline Age in year & $0.027^{* * *}$ & 0.004 & $0.038^{* * *}$ & 0.003 & $0.057^{* * *}$ & 0.004 & $0.047^{* * * *}$ & 0.003 \\
\hline Age squared/100 & $-0.027^{* * *}$ & 0.006 & $-0.051^{* * *}$ & 0.004 & $-0.064^{* * *}$ & 0.006 & $-0.064^{* * *}$ & 0.004 \\
\hline Receives pension & $-0.053^{*}$ & 0.030 & $-0.114^{* * *}$ & 0.020 & $-0.101^{* * *}$ & 0.027 & -0.027 & 0.017 \\
\hline \multicolumn{9}{|l|}{ Education } \\
\hline Primary School & $0.270^{* *}$ & 0.108 & $-0.574^{* * *}$ & 0.072 & 0.079 & 0.172 & $-0.601^{* * *}$ & 0.106 \\
\hline Incomplete Secondary & $0.109^{* * * *}$ & 0.029 & $-0.431^{* * *}$ & 0.019 & $0.167^{* * *}$ & 0.032 & $-0.549^{* * *}$ & 0.020 \\
\hline Incom. secondary/vocational & $0.167^{* * *}$ & 0.034 & $-0.343^{* * *}$ & 0.023 & $0.174^{* * *}$ & 0.046 & $-0.553^{* * *}$ & 0.029 \\
\hline Secondary School & $0.103^{* * *}$ & 0.021 & $-0.281^{* * * *}$ & 0.014 & $0.123^{* * *}$ & 0.020 & $-0.415^{* * *}$ & 0.013 \\
\hline Secondary + vocational & $0.080^{* * *}$ & 0.022 & $-0.287^{* * *}$ & 0.015 & $0.131^{\text {*** }}$ & 0.022 & $-0.423^{* * *}$ & 0.014 \\
\hline College degree & $0.113^{* * *}$ & 0.022 & $-0.164^{* * *}$ & 0.015 & $0.110^{* * *}$ & 0.017 & $-0.268^{* * *}$ & 0.011 \\
\hline University and higher & \multicolumn{8}{|c|}{ Reference category } \\
\hline Work tenure in years & 0.002 & 0.002 & $0.006^{* * *}$ & 0.002 & $0.008^{* * * *}$ & 0.002 & $0.005^{* * *}$ & 0.001 \\
\hline Work ten & -0.000 & 0.000 & -0.000 & 0.000 & -0.000 & 0.000 & 0.000 & 0.000 \\
\hline Married & $0.095^{* * *}$ & 0.022 & $0.149^{* * *}$ & 0.015 & $-0.087^{* * *}$ & 0.015 & -0.008 & 0.010 \\
\hline \multicolumn{9}{|l|}{ Household Characteristics } \\
\hline Log of household size & 0.042 & 0.063 & $0.095^{* *}$ & 0.043 & -0.028 & 0.050 & $-0.078^{* *}$ & 0.031 \\
\hline Log of household size ${ }^{2}$ & 0.002 & 0.027 & $-0.037^{* *}$ & 0.018 & 0.008 & 0.023 & 0.021 & 0.015 \\
\hline Share of children & -0.016 & 0.047 & $0.124^{* * *}$ & 0.032 & -0.008 & 0.041 & $-0.148^{* * *}$ & 0.026 \\
\hline Share of pensioners & $-0.126^{* * *}$ & 0.046 & $-0.108^{* * *}$ & 0.031 & -0.056 & 0.041 & $-0.140^{* * *}$ & 0.026 \\
\hline \multicolumn{9}{|l|}{ Type of locality } \\
\hline Moscow and St. Petersburg & \multicolumn{8}{|c|}{ Reference category } \\
\hline City & $0.058^{*}$ & 0.031 & $0.099^{* * *}$ & 0.022 & $0.142^{* * *}$ & 0.029 & $-0.094^{* * *}$ & 0.019 \\
\hline Town & $0.281^{* * *}$ & 0.033 & $0.152^{* * * *}$ & 0.023 & $0.362^{* * *}$ & 0.031 & $-0.078^{* * *}$ & 0.020 \\
\hline Small Town & $0.330^{* * *}$ & 0.042 & $0.120^{* * *}$ & 0.030 & $0.325^{* * *}$ & 0.039 & $-0.055^{* *}$ & 0.025 \\
\hline Village & $0.414^{* * *}$ & 0.033 & $-0.133^{* * *}$ & 0.025 & $0.444^{* * *}$ & 0.031 & $-0.269^{* * *}$ & 0.021 \\
\hline Log Mean Regional Wage & & & $0.970^{* * * *}$ & 0.019 & & & $0.828^{* * * *}$ & 0.017 \\
\hline Constant term & & & -0.299 & 0.206 & & & $1.063^{* * *}$ & 0.178 \\
\hline Auxiliary parameter 1 & $-0.252^{* *}$ & 0.100 & & & $0.434^{* * *}$ & 0.095 & & \\
\hline Auxiliary parameter 2 & $0.399^{* * *}$ & 0.100 & & & $1.033^{* * *}$ & 0.096 & & \\
\hline Auxiliary parameter 3 & $0.733^{* * *}$ & 0.100 & & & $1.343^{* * *}$ & 0.096 & & \\
\hline Auxiliary parameter 4 & $1.549^{* * *}$ & 0.100 & & & $2.078^{* * *}$ & 0.096 & & \\
\hline Number of observations & \multicolumn{2}{|c|}{23,248} & \multicolumn{2}{|c|}{23.378} & & \multicolumn{2}{|c|}{26,233} \\
\hline Log-likelihood & \multicolumn{2}{|c|}{$-35,856.26$} & \multicolumn{2}{|c|}{$-26,656.06$} & \multicolumn{2}{|c|}{$-39,692.96$} & \multicolumn{2}{|c|}{$-27,910.70$} \\
\hline Adjusted/Pseudo R2 & \multicolumn{2}{|c|}{0.017} & \multicolumn{2}{|c|}{0.528} & \multicolumn{2}{|c|}{0.021} & \multicolumn{2}{|c|}{0.573} \\
\hline
\end{tabular}

Note: ${ }^{*}$ is significant at $10 \%$ level; ${ }^{* *}$ is significant at $5 \%$ level; ${ }^{* * * *}$ is significant at $1 \%$ level. Standard errors are estimated by bootstrapping. Coefficients for year dummies and region dummies are omitted. 
Table 4: Fear of Losing Job. Ordered probit estimations and Fixed Effect regressions for wage equations for men and women. Pooled sample of working age adults, 2000-2009, RLMS.

\begin{tabular}{|c|c|c|c|c|c|c|c|c|}
\hline & \multicolumn{4}{|c|}{ Men } & \multicolumn{4}{|c|}{ Women } \\
\hline & \multicolumn{2}{|c|}{ Ordered Probit } & \multicolumn{2}{|c|}{$\begin{array}{c}\mathrm{FE} \\
\text { Wage regression }\end{array}$} & \multicolumn{2}{|c|}{ Ordered Probit } & \multicolumn{2}{|c|}{$\begin{array}{c}\mathrm{FE} \\
\text { Wage regression }\end{array}$} \\
\hline & Coeff. & Std.Err & Coeff. & Std.Err & Coeff. & Std.Err & Coeff. & Std.Err \\
\hline Log Wage Residuals & $0.030^{* *}$ & 0.015 & & & $0.084^{* * *}$ & 0.016 & & \\
\hline $\begin{array}{l}\text { Regional unemployment } \\
\text { Individual Characteristics }\end{array}$ & \multicolumn{7}{|c|}{ Individual Characteristics } & 0.003 \\
\hline Age in year & $0.026^{* * *}$ & 0.005 & $0.092^{* * * *}$ & 0.018 & $0.059^{* * * *}$ & 0.005 & $0.110^{* * * *}$ & 0.020 \\
\hline Age squared/100 & $-0.021^{* * *}$ & 0.000 & $-0.001^{* * *}$ & 0.000 & $-0.001^{* * *}$ & 0.000 & $-0.001^{* * *}$ & 0.000 \\
\hline Receives pension & -0.048 & 0.030 & $-0.104^{* * * *}$ & 0.030 & $-0.102^{* * *}$ & 0.027 & $-0.092^{* * *}$ & 0.020 \\
\hline \multicolumn{9}{|l|}{ Education } \\
\hline Primary School & $0.359^{* * *}$ & 0.112 & -0.049 & 0.130 & 0.162 & 0.181 & -0.029 & 0.192 \\
\hline Incomplete secondary & $0.104^{* * *}$ & 0.030 & $-0.117^{* *}$ & 0.046 & $0.167^{* * *}$ & 0.033 & $-0.145^{* * *}$ & 0.043 \\
\hline Incom. secondary/vocational & $0.171^{* * *}$ & 0.034 & $-0.093^{* *}$ & 0.045 & $0.169^{* * *}$ & 0.047 & $-0.206^{* * *}$ & 0.045 \\
\hline Secondary School & $0.104^{* * *}$ & 0.022 & $-0.122^{* * *}$ & 0.038 & $0.122^{* * *}$ & 0.021 & $-0.149^{* * *}$ & 0.029 \\
\hline Secondary + vocational & $0.078^{* * *}$ & 0.022 & $-0.103^{* * *}$ & 0.039 & $0.136^{* * *}$ & 0.023 & $-0.126^{* * *}$ & 0.031 \\
\hline College degree & $0.119^{* * * *}$ & 0.023 & -0.030 & 0.037 & $0.121^{* * *}$ & 0.018 & $-0.085^{* * *}$ & 0.026 \\
\hline University and higher & \multicolumn{8}{|c|}{ Reference category } \\
\hline Work tenure in years & 0.002 & 0.002 & $-0.006^{* *}$ & 0.002 & $0.007^{* * *}$ & 0.002 & $-0.006^{* * * *}$ & 0.002 \\
\hline Work tenure squared & -0.000 & 0.000 & $0.000^{* * *}$ & 0.000 & -0.000 & 0.000 & $0.000^{* * *}$ & 0.000 \\
\hline Married & $0.100^{* * * *}$ & 0.023 & 0.003 & 0.025 & $-0.086^{* * *}$ & 0.016 & 0.014 & 0.016 \\
\hline \multicolumn{9}{|l|}{ Household Characteristics } \\
\hline Log of household size & -0.023 & 0.066 & -0.021 & 0.065 & -0.017 & 0.052 & -0.043 & 0.044 \\
\hline Log of household size ${ }^{2}$ & 0.030 & 0.028 & -0.029 & 0.028 & 0.001 & 0.024 & 0.013 & 0.021 \\
\hline Share of children & -0.016 & 0.049 & $0.153^{* * * *}$ & 0.048 & -0.018 & 0.042 & -0.050 & 0.036 \\
\hline Share of pensioners & $-0.131^{* * *}$ & 0.047 & 0.050 & 0.052 & -0.053 & 0.042 & 0.005 & 0.037 \\
\hline \multicolumn{9}{|l|}{ Type of locality } \\
\hline Moscow and St. Petersburg & \multicolumn{8}{|c|}{ Reference category } \\
\hline City & $0.077^{* *}$ & 0.032 & & & $0.150^{* * *}$ & 0.030 & & \\
\hline Town & $0.296^{* * * *}$ & 0.034 & & & $0.364^{* * *}$ & 0.032 & & \\
\hline Small Town & $0.350^{* * * *}$ & 0.043 & $2.257^{* * * *}$ & 0.680 & $0.318^{* * *}$ & 0.040 & & \\
\hline Village & $0.432^{* * * *}$ & 0.034 & & & $0.445^{* * *}$ & 0.032 & & \\
\hline Log Mean Regional Wage & & & $0.841^{* * * *}$ & 0.048 & & & $0.415^{* * *}$ & 0.038 \\
\hline Constant term & & & -0.196 & 0.852 & & & $2.960^{* * * *}$ & 0.909 \\
\hline Auxiliary parameter 1 & $-0.313^{* * *}$ & 0.106 & & & $0.495^{* * *}$ & 0.100 & & \\
\hline Auxiliary parameter 2 & $0.338^{* * *}$ & 0.106 & & & $1.095^{* * *}$ & 0.100 & & \\
\hline Auxiliary parameter 3 & $0.672^{* * * *}$ & 0.106 & & & $1.404^{* * *}$ & 0.100 & & \\
\hline Auxiliary parameter 4 & $1.491^{* * *}$ & 0.106 & & & $2.139^{* * *}$ & 0.101 & & \\
\hline Number of observations & \multicolumn{2}{|c|}{21,882} & \multicolumn{2}{|c|}{21,997} & \multicolumn{2}{|c|}{24,754} & \multicolumn{2}{|c|}{24,862} \\
\hline Log-likelihood & \multicolumn{2}{|c|}{$-32,868.80$} & \multicolumn{2}{|c|}{$-15,346.02$} & \multicolumn{2}{|c|}{$-36,951.24$} & \multicolumn{2}{|c|}{$-14,417.77$} \\
\hline Adjusted/Pseudo R2 & \multicolumn{2}{|c|}{0.017} & \multicolumn{2}{|c|}{0.353} & \multicolumn{2}{|c|}{0.020} & \multicolumn{2}{|c|}{0.499} \\
\hline
\end{tabular}

Note: ${ }^{*}$ is significant at $10 \%$ level; ${ }^{* *}$ is significant at $5 \%$ level; ${ }^{* * *}$ is significant at $1 \%$ level. Standard errors are estimated by bootstrapping. Coefficients for year dummies and region dummies are omitted. 
Table 5: Fear of Losing Job. Semi-nonparametric Maximum Likelihood estimations and Fixed Effect regression estimations for wage equations for men and women. Pooled sample of working age adults, 2000-2009, RLMS.

\begin{tabular}{|c|c|c|c|c|c|c|c|c|}
\hline & \multicolumn{4}{|c|}{ Men } & \multicolumn{4}{|c|}{ Women } \\
\hline & \multirow{2}{*}{\multicolumn{2}{|c|}{ SNPML }} & \multirow{2}{*}{\multicolumn{2}{|c|}{$\begin{array}{c}\mathrm{FE} \\
\text { Wage regression }\end{array}$}} & \multirow{2}{*}{\multicolumn{2}{|c|}{ SNPML }} & \multirow{2}{*}{\multicolumn{2}{|c|}{$\begin{array}{c}\mathrm{FE} \\
\text { Wage regression }\end{array}$}} \\
\hline & & & & & & & & \\
\hline & Coeff. & Std.Err & Coeff. & Std.Err & Coeff. & Std.Err & Coeff. & Std.Err \\
\hline Log Wage Residuals & $0.036^{*}$ & 0.019 & & & $0.077^{* * *}$ & 0.017 & & \\
\hline Regional unemployment & 0.007 & 0.005 & 0.003 & 0.004 & $0.017^{* * *}$ & 0.004 & -0.000 & 0.003 \\
\hline \multicolumn{9}{|l|}{ Individual Characteristics } \\
\hline Age in year & $0.030^{* * *}$ & 0.006 & $0.092^{* * *}$ & 0.018 & $0.057^{* * *}$ & 0.005 & $0.110^{* * *}$ & 0.020 \\
\hline Age squared/100 & $-0.030^{* * *}$ & 0.007 & $-0.001^{* * * *}$ & 0.000 & $-0.062^{* * *}$ & 0.006 & $-0.001^{* * * *}$ & 0.000 \\
\hline Receives pension & -0.037 & 0.039 & $-0.104^{* * *}$ & 0.030 & $-0.116^{* * *}$ & 0.030 & $-0.092^{* * * *}$ & 0.020 \\
\hline \multicolumn{9}{|l|}{ Education } \\
\hline Primary School & $0.393^{* * *}$ & 0.149 & -0.049 & 0.130 & 0.136 & 0.174 & -0.029 & 0.192 \\
\hline Incomplete secondary & $0.131^{* * *}$ & 0.038 & $-0.117^{* *}$ & 0.046 & $0.196^{* * *}$ & 0.037 & $-0.145^{* * *}$ & 0.043 \\
\hline Incom. secondary/vocational & $0.203^{* * *}$ & 0.043 & $-0.093^{* *}$ & 0.045 & $0.160^{* * *}$ & 0.051 & $-0.206^{* * *}$ & 0.045 \\
\hline Secondary School & $0.143^{* * *}$ & 0.029 & $-0.122^{* * *}$ & 0.038 & $0.122^{* * *}$ & 0.023 & $-0.149^{* * *}$ & 0.029 \\
\hline Secondary + vocational & $0.112^{* * *}$ & 0.028 & $-0.103^{* * *}$ & 0.039 & $0.148^{* * *}$ & 0.026 & $-0.126^{* * *}$ & 0.031 \\
\hline College degree & $0.145^{* * *}$ & 0.029 & -0.030 & 0.037 & $0.127^{* * * *}$ & 0.020 & $-0.085^{* * *}$ & 0.026 \\
\hline University and higher & \multicolumn{8}{|c|}{ Reference category } \\
\hline Work tenure in years & 0.002 & 0.003 & $-0.006^{* *}$ & 0.002 & $0.007^{* * *}$ & 0.002 & $-0.006^{* * *}$ & 0.002 \\
\hline Work tenure squared & 0.000 & 0.000 & $0.000^{* *}$ & 0.000 & -0.000 & 0.000 & $0.000^{* * *}$ & 0.000 \\
\hline Married & $0.143^{* * *}$ & 0.029 & 0.003 & 0.025 & $-0.090^{* * *}$ & 0.018 & 0.014 & 0.016 \\
\hline \multicolumn{9}{|l|}{ Household Characteristics } \\
\hline Log of household size & -0.037 & 0.084 & -0.021 & 0.065 & -0.003 & 0.054 & -0.043 & 0.044 \\
\hline Log of household size ${ }^{2}$ & 0.048 & 0.036 & -0.029 & 0.028 & -0.006 & 0.025 & 0.013 & 0.021 \\
\hline Share of children & -0.030 & 0.061 & $0.153^{* * *}$ & 0.048 & -0.011 & 0.045 & -0.050 & 0.036 \\
\hline Share of pensioners & $-0.192^{* * *}$ & 0.060 & 0.050 & 0.052 & -0.071 & 0.045 & 0.005 & 0.037 \\
\hline \multicolumn{9}{|l|}{ Type of locality } \\
\hline Moscow and St. Petersburg & \multicolumn{8}{|c|}{ Reference category } \\
\hline City & $0.092^{* *}$ & 0.041 & & & $0.180^{* * *}$ & 0.033 & & \\
\hline Town & $0.366^{* * *}$ & 0.045 & & & $0.405^{* * *}$ & 0.041 & & \\
\hline Small Town & $0.479^{* * *}$ & 0.061 & $2.257^{* * * *}$ & 0.680 & $0.369^{* * *}$ & 0.049 & & \\
\hline Village & $0.585^{* * *}$ & 0.050 & & & $0.513^{* * *}$ & 0.047 & & \\
\hline Log Mean Regional Wage & & & $0.841^{* * *}$ & 0.048 & & & $0.415^{* * *}$ & 0.038 \\
\hline Constant term & & & -0.196 & 0.852 & & & $2.960^{* * * *}$ & 0.909 \\
\hline Auxiliary parameter 1 & Fixed & & & & Fixed & & & \\
\hline Auxiliary parameter 2 & $0.648^{* * *}$ & 0.043 & & & $1.248^{* * * *}$ & 0.050 & & \\
\hline Auxiliary parameter 3 & $1.139^{* * *}$ & 0.065 & & & $1.616^{* * * *}$ & 0.075 & & \\
\hline Auxiliary parameter 4 & $2.117^{* * *}$ & 0.097 & & & $2.375^{* * *}$ & 0.121 & & \\
\hline Number of observations & \multicolumn{2}{|c|}{21,341} & \multicolumn{2}{|c|}{21,997} & \multicolumn{2}{|c|}{24,352} & \multicolumn{2}{|c|}{24,862} \\
\hline Log-likelihood & \multirow{2}{*}{\multicolumn{2}{|c|}{$-32,824.11$}} & \multirow{2}{*}{\multicolumn{2}{|c|}{$\begin{array}{c}-15,346.02 \\
0.353\end{array}$}} & \multirow{2}{*}{\multicolumn{2}{|c|}{$-36,910.81$}} & \multirow{2}{*}{\multicolumn{2}{|c|}{$\begin{array}{c}-14,417.77 \\
0.499\end{array}$}} \\
\hline Adjusted/Pseudo R2 & & & & & & & & \\
\hline
\end{tabular}

Note: ${ }^{*}$ is significant at $10 \%$ level; ${ }^{* *}$ is significant at $5 \%$ level; ${ }^{* * *}$ is significant at $1 \%$ level. Standard errors are estimated by bootstrapping. Coefficients for year dummies and region dummies are omitted. 
Table 6: Fear of not finding a job at least as good as the current one. Pooled sample of working age adults, 2000-2009, RLMS.

\begin{tabular}{|c|c|c|c|c|}
\hline & \multicolumn{2}{|c|}{ Men } & \multicolumn{2}{|c|}{ Women } \\
\hline & Coefficient & Standard Error & Coefficient & Standard Error \\
\hline & \multicolumn{4}{|c|}{ Ordered probit with wage residual from OLS regression } \\
\hline Wage Residuals & 0.011 & 0.010 & $0.079^{* * *}$ & 0.010 \\
\hline Regional unemployment & $0.013^{* * * *}$ & 0.004 & $0.024^{* * *}$ & 0.004 \\
\hline \multicolumn{5}{|c|}{ Ordered probit with wage residual from $F E$ regression } \\
\hline Wage Residuals & $0.053^{* * * *}$ & 0.016 & $0.106^{* * *}$ & 0.017 \\
\hline Regional unemployment & $0.015^{* * * *}$ & 0.004 & $0.024^{* * *}$ & 0.004 \\
\hline \multicolumn{5}{|c|}{$S N P M L$ with wage residual from $F E$ regression } \\
\hline Wage Residuals & $0.052^{* * * *}$ & 0.020 & $0.138^{* * *}$ & 0.029 \\
\hline Regional unemployment & $0.019^{* * * *}$ & 0.006 & $0.038^{* * * *}$ & 0.007 \\
\hline
\end{tabular}

Note: ${ }^{*}$ is significant at $10 \%$ level; ${ }^{* *}$ is significant at $5 \%$ level; ${ }^{* * *}$ is significant at $1 \%$ level. Standard errors are estimated by bootstrapping. Coefficients for other explanatory variables are omitted.

Table 7: Fear of losing a job. Specifications with unemployment rates imputed from Russia LFS. Pooled sample of working age adults, 2000-2009, RLMS.

\begin{tabular}{|c|c|c|c|c|c|c|c|c|}
\hline & \multicolumn{4}{|c|}{ Group-specific Unemployment } & \multicolumn{4}{|c|}{ Group-specific Non-Employment } \\
\hline & \multicolumn{2}{|c|}{ Men } & \multicolumn{2}{|c|}{ Women } & \multicolumn{2}{|c|}{ Men } & \multicolumn{2}{|c|}{ Women } \\
\hline & Coeff. & Std. Err. & Coeff. & Std. Err. & Coeff. & Std. Err. & Coeff. & Std. Err. \\
\hline & \multicolumn{8}{|c|}{ Ordered probit with wage residual from OLS regression } \\
\hline Wage Residuals & $0.040^{* * *}$ & 0.010 & $0.080^{* * *}$ & 0.010 & $0.040^{* * *}$ & 0.010 & $0.079^{* * *}$ & 0.010 \\
\hline \multirow[t]{2}{*}{ Regional unemployment } & 0.000 & 0.001 & $0.002^{* *}$ & 0.001 & $0.003^{* * *}$ & 0.001 & $0.004^{* * *}$ & 0.001 \\
\hline & \multicolumn{8}{|c|}{ Ordered probit with wage residual from $F E$ regression } \\
\hline Wage Residuals & $0.033^{* *}$ & 0.015 & $0.091^{* * *}$ & 0.017 & $0.033^{* *}$ & 0.015 & $0.091^{* * *}$ & 0.017 \\
\hline \multirow[t]{2}{*}{ Regional unemployment } & 0.001 & 0.001 & $0.002^{* *}$ & 0.001 & $0.003^{* * *}$ & 0.001 & $0.004^{* * * *}$ & 0.001 \\
\hline & \multicolumn{8}{|c|}{$S N P M L$ with wage residual from $F E$ regression } \\
\hline Wage & $0.039^{* *}$ & 0.019 & $0.084^{* * *}$ & 0.019 & $0.039^{* *}$ & 0.019 & $0.086^{* * *}$ & 0.020 \\
\hline Regional unemployment & 0.001 & 0.002 & $0.002^{*}$ & 0.001 & $0.004^{* * * *}$ & 0.001 & $0.003^{* *}$ & 0.001 \\
\hline
\end{tabular}

Note: ${ }^{*}$ is significant at $10 \%$ level; ${ }^{* *}$ is significant at $5 \%$ level; ${ }^{* * *}$ is significant at $1 \%$ level. Standard errors are estimated by bootstrapping. Coefficients for other explanatory variables are omitted. 

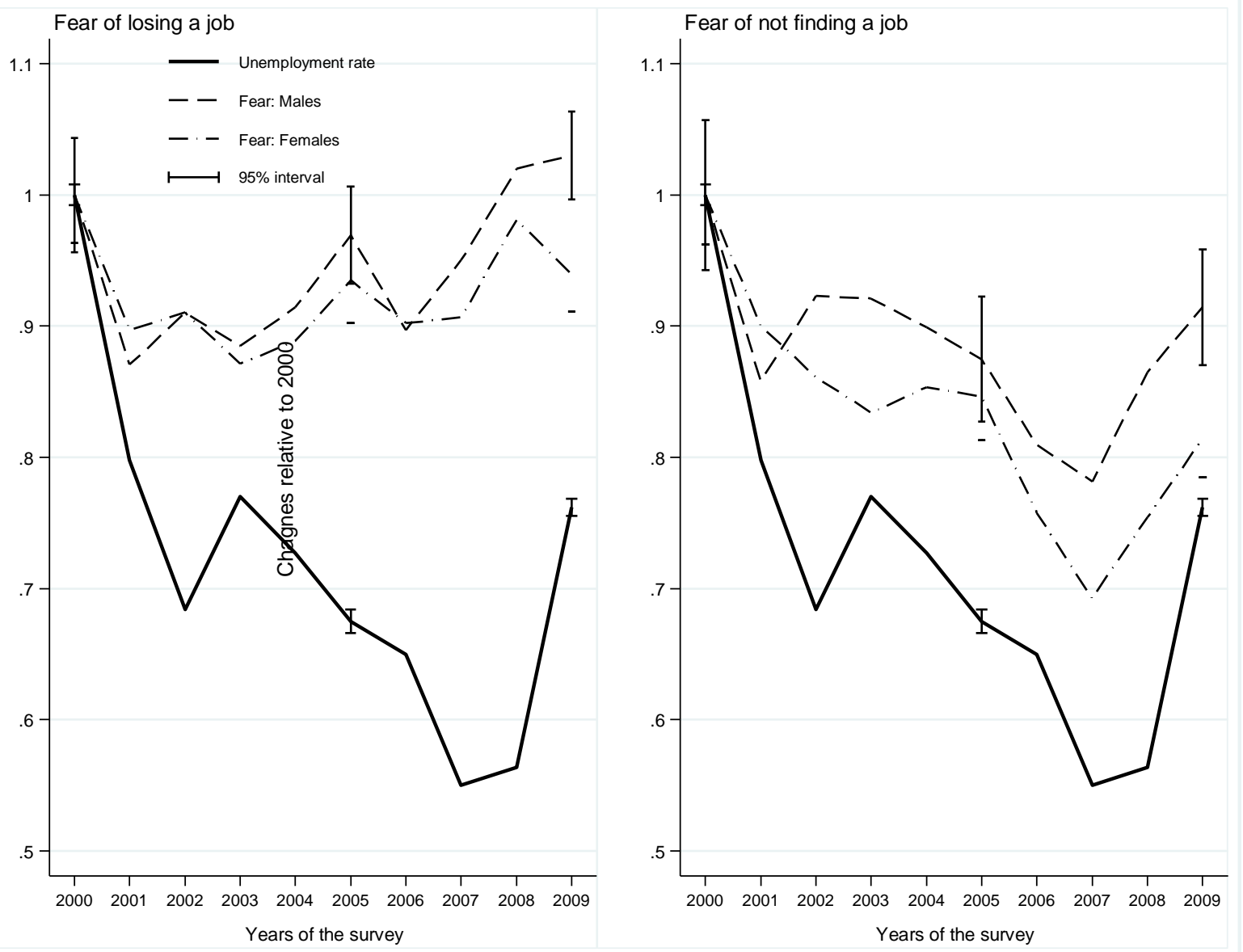

Figure 1: Changes in the perceptions of job security and unemployment rates normalized to the levels in 2000 for males and female and for rounds of RLMS. 

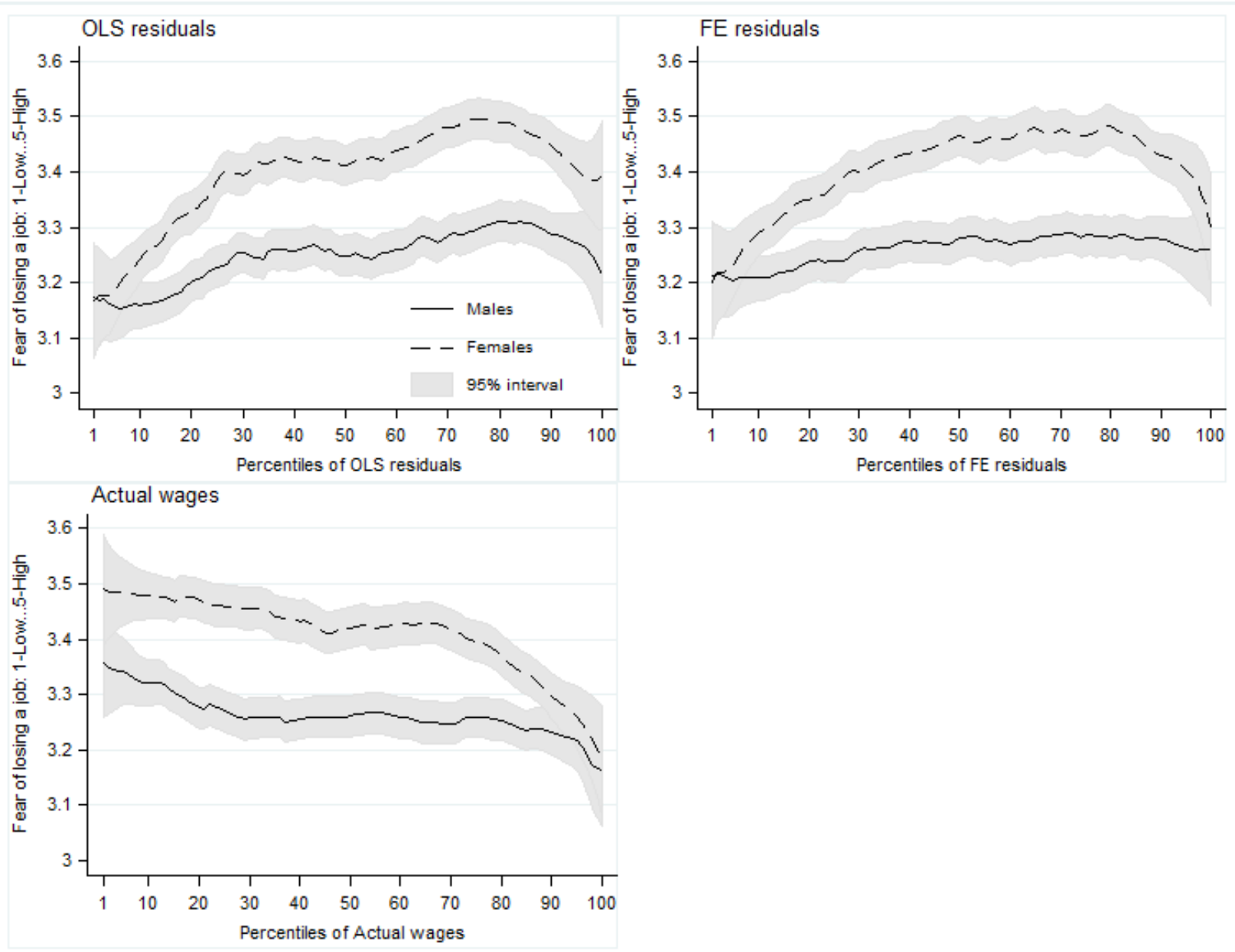

Figure 2: Does the fear of losing a job depend on the wage residuals or actual wages? Nonparametric smoothing estimation for men and women. Pooled sample of working age adults RLMS 2000-2001. 

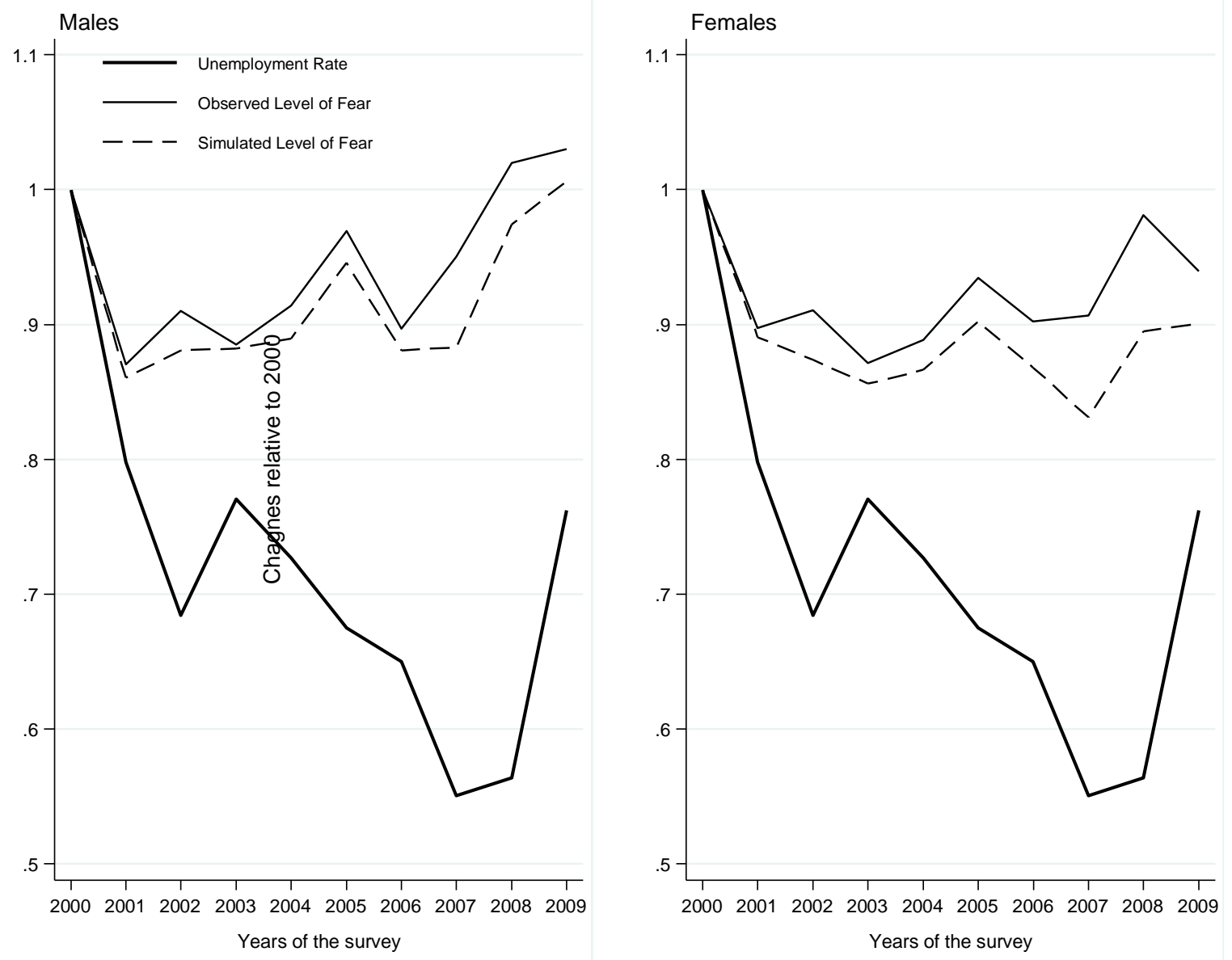

Figure 3: Changes in the actual and simulated fears of losing a job for males and females and changes in unemployment rate normalized to the levels in 2000 for rounds of RLMS. 


\section{Appendix}

Table A1: Are the respondents most fearful of losing their jobs more likely to become unemployed? Probit estimations of employment status for men and women.

\begin{tabular}{|c|c|c|c|c|}
\hline & \multicolumn{2}{|c|}{ Men } & \multicolumn{2}{|c|}{ Women } \\
\hline & Coeff. & Std.Err & Coeff. & Std.Err \\
\hline Fear of losing a job $(4,5)$ last year & -0.024 & 0.041 & -0.006 & 0.042 \\
\hline Regional unemployment & $0.039^{* * *}$ & 0.008 & 0.011 & 0.009 \\
\hline \multicolumn{5}{|l|}{ Individual Characteristics } \\
\hline Age in year & -0.020 & 0.015 & $-0.048^{* *}$ & 0.019 \\
\hline Age squared/100 & 0.022 & 0.020 & $0.044^{*}$ & 0.026 \\
\hline Receives pension & $0.211^{* * *}$ & 0.076 & -0.153 & 0.113 \\
\hline \multicolumn{5}{|l|}{ Education } \\
\hline Primary or Incomplete secondary & $0.311^{* * *}$ & 0.079 & $0.260^{* * *}$ & 0.092 \\
\hline Vocational & 0.105 & 0.100 & $0.223^{*}$ & 0.135 \\
\hline Secondary School & $0.172^{* * *}$ & 0.066 & $0.227^{* * *}$ & 0.063 \\
\hline Secondary + vocational & $0.125^{*}$ & 0.067 & $0.223^{* * *}$ & 0.066 \\
\hline College degree & 0.077 & 0.073 & 0.039 & 0.060 \\
\hline University and higher & \multicolumn{4}{|c|}{ Reference category } \\
\hline Married & $-0.325^{* * *}$ & 0.059 & -0.062 & 0.048 \\
\hline \multicolumn{5}{|l|}{ Household Characteristics } \\
\hline Log of household size & 0.179 & 0.175 & -0.258 & 0.158 \\
\hline Log of household size ${ }^{2}$ & -0.068 & 0.075 & 0.102 & 0.072 \\
\hline Share of children & -0.168 & 0.143 & $-0.222^{*}$ & 0.130 \\
\hline Share of pensioners & 0.245 & 0.150 & -0.047 & 0.187 \\
\hline \multicolumn{5}{|l|}{ Type of locality } \\
\hline Moscow and St. Petersburg & \multicolumn{4}{|c|}{ Reference category } \\
\hline City & $-0.174^{*}$ & 0.091 & 0.003 & 0.093 \\
\hline Town & -0.027 & 0.092 & -0.066 & 0.098 \\
\hline Small Town & -0.003 & 0.119 & 0.017 & 0.122 \\
\hline Village & -0.031 & 0.094 & -0.063 & 0.099 \\
\hline Constant term & $-1.987^{* * *}$ & 0.325 & $-0.872^{* *}$ & 0.346 \\
\hline Number of observations & \multicolumn{2}{|c|}{19,839} & \multicolumn{2}{|c|}{21,607} \\
\hline Log-likelihood & \multicolumn{2}{|c|}{$-2,067.59$} & \multicolumn{2}{|c|}{$-1,949.83$} \\
\hline Adjusted/Pseudo R2 & \multicolumn{2}{|c|}{0.041} & \multicolumn{2}{|c|}{0.035} \\
\hline
\end{tabular}

Note: ${ }^{*}$ is significant at $10 \%$ level; ${ }^{* *}$ is significant at $5 \%$ level; ${ }^{* * *}$ is significant at $1 \%$ level. Coefficients for year dummies and region dummies are omitted. 